\title{
Influence of Work Well-being on Employees-Mediating Role of Organizational Identification and Managerial Support
}

\author{
Arpita Banik \\ Istanbul Aydin University, Institute of Graduate Students, Department of Business Administration (English) \\ arpitananik@gmail.com
}

\begin{abstract}
The purpose of this research is to comprehend the impact of technostress on employees' well-being: the role of work engagement and perceived supervisor support. This research is conducted in a developing country of Iraq during COVID-19 as a contextual variable where no previous literature in this context could be found which is considered as a scientific gap and needs to be explored. The population of this study is Iraqi employees. As for the research sample, it is limited to any Iraqi employee who used ICT in any organizations on a daily basis. A self-administered questionnaire distributed via Google forms online. The convenient snowball sampling method was used on social media and personal contacts as it lets respondents recruit others through liking, commenting, or sharing the post. A total of 179 individuals participated in the survey. As for the finding, controlling for age, gender, education, and computer literacy, we found that there is no significant relationship between technostress and work engagement, and technostress and perceived supervisor support unlike what is written in the literature. However, a significant positive relationship between perceived supervisor support and work engagement has been found we presume it's the impact of COVID-19 which made employees depend on supervisors for support. The practical implication of this research demonstrates that technostress may have different impacts depending on location and time. HR and organizations in Iraq can make use of this research and utilize it as a benchmark to measure well-being in their organizations.
\end{abstract}

Keywords: technostress, employee well-being, work Engagement, perceived supervisor support, COVID-19

\section{Introduction}

The world has become a "room" no longer a "global village" with the arrival of the fast technology [2]. The Coronavirus pandemic proved that when one person on the edge of the world infected with the coronavirus could spread the virus to another person on the other edge of the world as if they are all in the same room. The year 2020 has changed the global economy and world of work drastically when the World Health Organization (WHO) has declared the novel virus as a pandemic and urged all governments to take serious measures to "flatten the curve" [13].

The use of Information and communication technologies (ICT) has made working more efficient such as teleworking. Also, even traditional sectors which did not use IT before, such as agriculture are now using ICT to compete with their industry [15]. Further, employees' continuous connectivity with technology leads to work speed which enhances productivity and quality of individual life. However, according to the same research technology is a "double-edged sword".

The downside of technology is called technostress, which is first explained by [9] as "a modern disease of adaptation caused by the inability to cope with new technologies in a healthy manner" and it is becoming more common during the COVID-19 pandemic [32]. Further, [25] explained technostress as an adaptation problem due to an employee's inability to use ICT. Moreover, the advantages of ICTs put employees under more pressure because they are predicted to perform faster and more productive and be "always on" and reachable. This culture of "always connected" led employees to be burned out, absent at work more often, exhausted, and less engaged, which impacts their overall performance and wellbeing [24].

Moreover, employee's well-being has received a great deal of attention in the literature recently when it comes to technostress. The COVID-19 pandemic has put more pressure on organizations to keep a sense of community between their employees and support their well-being. According to [26] $12 \%$ of European Union workers felt isolated and $25 \%$ felt emotionally drained by their work during the coronavirus pandemic. In addition, $73 \%$ of American employees experienced stress at work in 2012 and this percentage reached $82 \%$ in 2013 as cited in [14].

In addition, the role of social support in relation to technostress has been studied to some extent. For example, it has been proven that little support from a supervisor prevents negative mental consequences such as depression, absenteeism, turnover, etc. [26]. Additionally, social support offers a promising field and nowadays is one of the most used researched coping mechanisms. Organizations have a difficult job to both give employees the technology they need while keeping them away from "self-inflicted work life conflict" according to [38].

In addition, technostress has a negative effect of workers' health and damage employee's well-being. Social support has a big role in managing job demands in our case ICT demands. Social support can help the workers deal with the technology in an effective way which in turn reduces its negative effects such as technostress. More, social support has been a point of great interest for researchers and practitioners because it is directly related to psychological and physical well-being. According to research, those who are supported can keep their psychological and physical 
well-being even in stressful situation or in their life in general.

\section{Literature Review}

\subsection{Technostress}

Stress has become an epidemic and one of the biggest health threats to humanities. Research also supports the motion that continuous stress at work impacts employees' performance and results in major health problems or even emotional exhaustion [23]. Further, [25] defined the phrase "under stress" as a condition felt by someone when an environmental situation is thought to be demanding and threatens go beyond the person's abilities and resources, in a condition where the person predicts a considerable difference in rewards and costs for meeting that demand or not meeting it. Moreover, it has also defined stress as a psychological response to a kind of imbalance between a person and the environment surrounding it as cited [25].

The COVID-19 pandemic has turned the lives of workers upside down globally. with the emergence of the pandemic social distancing happened to all of us, employees lost their jobs, they also faced job insecurities, along with losing work-home boundaries, and worried over the health of themselves and the loved ones, etc. Employees started working remotely or as known more commonly as "teleworking", most of the first time, overnight. These changes, along with many more, also affected work-family conflicts. Some of them depended on their colleagues for support, others created boundaries between work and home/family [42].

Furthermore, [26] did research on the COVID-19 anxiety among workers in Finland and found out that technology has indeed helped employees with getting crucial resources for work and well-being. But it also showed that not all employees can easily use computers/technology that might result in technostress. It showed that employees who work remotely actually dedicate more work hours because they think they are obliged to work longer hours, and with the high workload, which results in more techno-stressors like technology invasion into their lives [26].

Moreover, everyone can get stressed. But there are two types of stress: eustress and distress. Eustress, also known as "normal or beneficial type" of stress [18] is when an individual feels IS as a challenging task to overcome, and that stress leads to a positive outcome. However, distress also known as a bad stress is when someone feels fatigued and it basically a process where an individual believes information system is a threat and results in not favorable outcomes, [40]. Additionally, to apply the idea of stress to a situation where there is a difference between the demand of the environment and the person's reaction to it should be great and the results anticipated from not meeting that demand considerable too. According to [25] stress leads to dissatisfaction at work, poor performance and job involvement. Research show that technology is one of the causes of stress.

Research on the impact of technology-induced stress was not so popular or a point of interest for a long time. Digital technology changed this, and it became omnipresent in virtually every business branch and its infusion with parts of organizations has led to a big structure change in organizations, changed communication, employee relations and business models. Research by [16] indicates that the most technological usage of technology is cellphones and computers. Nonetheless, the explosive growth of technology gave birth to technostress as cited in [8]. In the recent years, there are much research on the term "Technostress" [25] all due to the explosive development of the users' computing technologies. Some sources of technostress are emails, messaging apps, pagers, social media etc. [16] also demonstrates that computers and mobile phones interfere with employees' personal times. A short overview of Technostress is provided in Table 1.

Research confirms that some factors lead to technostress, and they are known as "technostress creators" which include techno-overload, techno-insecurity, technoinsecurity, techno-invasion, techno-uncertainty and technocomplexity. However, organizational mechanism that reduces the effects of technostress on employees are known as technostress inhibitors which include technical support, literacy facilitation, and involvement facilitation [17] \& [25]. Literature considers Perceived supervisor support (PSS), technology efficacy, adjusting regulatory focus as other kind of technostress inhibitors, [44].

Literature recently has showed that the big five personality traits (openness to experience, conscientiousness, extraversion, neuroticism, and agreeableness), have a relationship on the way technostress is experienced and decreased its [36]. Moreover, [37] has shown that the different individuals with different personality characteristics might see the technostress creators at the workplace in a different way leading to distress or eustress.

Literature shows several negative effects of technostress in the context of workplace such as behaviors which are disruptive, work dissatisfaction, lack of job involvement, bad work performance, job demand ambiguity, and decreased well-being, absenteeism, increasing of strain, exhaustion, and burnout, reduced innovation ability, not willing compliance or noncompliance of technology requirement which are put by the organization like fast email reply [36]. 
Table1: Literature review of Technostress research, source: [17]

\begin{tabular}{|c|c|c|c|c|c|}
\hline Research & Context & Antecedents & Techno-stressors & $\begin{array}{c}\text { Psychology \& } \\
\text { behaviors strains }\end{array}$ & Controls \\
\hline $\begin{array}{l}\text { Tu et } \\
\text { al.2005 }\end{array}$ & Organization & N/A & $\begin{array}{l}\text { uncertainty, invasion, } \\
\text { overload, insecurity and } \\
\text { complexity }\end{array}$ & Productivity & $\begin{array}{l}\text { Age, computer } \\
\text { literacy, task } \\
\text { complexity \& } \\
\text { rewards }\end{array}$ \\
\hline $\begin{array}{l}\text { Tarafdar } \\
\text { et al.2007 }\end{array}$ & Organization & N/A & $\begin{array}{l}\text { uncertainty, invasion, } \\
\text { overload, insecurity and } \\
\text { complexity }\end{array}$ & $\begin{array}{c}\text { role overload, } \\
\text { productivity, role } \\
\text { conflict, and role } \\
\text { stress }\end{array}$ & N/A \\
\hline $\begin{array}{l}\text { Ragu- } \\
\text { Nathan et } \\
\text { al.2008 }\end{array}$ & Organization & $\begin{array}{l}\text { Individual characteristics (age, } \\
\text { gender, education, computer } \\
\text { confidence) }\end{array}$ & $\begin{array}{l}\text { uncertainty, invasion, } \\
\text { overload, insecurity and } \\
\text { complexity }\end{array}$ & $\begin{array}{l}\text { Job satisfaction, } \\
\text { organizational } \\
\text { commitment, } \\
\text { continuance } \\
\text { commitment } \\
\end{array}$ & $\begin{array}{l}\text { Inhibiting } \\
\text { mechanism }\end{array}$ \\
\hline $\begin{array}{l}\text { Wang et } \\
\text { al.2008 }\end{array}$ & Organization & $\begin{array}{l}\text { characteristics (age, and education } \\
\text { and gender,) organizations } \\
\text { characteristics (centralizing and } \\
\text { innovating) } \\
\end{array}$ & $\begin{array}{l}\text { Overload, invasion, } \\
\text { complexity, insecurity, } \\
\text { uncertainty }\end{array}$ & N/A & N/A \\
\hline $\begin{array}{l}\text { Tarafdar } \\
\text { et al.2010 }\end{array}$ & Organization & $\begin{array}{c}\text { Organization characteristics } \\
\text { (facilitation, innovation, and } \\
\text { involvement) }\end{array}$ & $\begin{array}{c}\text { Overload, invasion, } \\
\text { complexity, insecurity, } \\
\text { uncertainty } \\
\end{array}$ & $\begin{array}{c}\text { End-user } \\
\text { satisfaction, end-user } \\
\text { performance } \\
\end{array}$ & N/A \\
\hline $\begin{array}{l}\text { Ayyagari } \\
\text { et al.2011 }\end{array}$ & Organization & $\begin{array}{l}\text { Technology characteristics } \\
\text { (usability features, dynamic } \\
\text { features, intrusive features) }\end{array}$ & $\begin{array}{l}\text { conflicts of work-home, } \\
\text { privacy invasion, work } \\
\text { overload, role ambiguity of } \\
\text { roles, and insecurity of } \\
\text { jobs }\end{array}$ & $\begin{array}{l}\text { Emotional } \\
\text { exhaustion }\end{array}$ & $\begin{array}{c}\text { negative } \\
\text { affectivity and } \\
\text { usage of } \\
\text { technology }\end{array}$ \\
\hline $\begin{array}{l}\text { Tafafdar } \\
\text { et al.2011 }\end{array}$ & Organization & $\begin{array}{l}\text { personal characteristics (computer, } \\
\text { age, gender, efficacy, education and } \\
\text { confidence, experience using } \\
\text { computers), inhibiting mechanism } \\
\text { (technical support provision, } \\
\text { technology involvement facilitation, } \\
\text { innovation support) }\end{array}$ & $\begin{array}{l}\text { Overload, invasion, } \\
\text { complexity, insecurity, } \\
\text { uncertainty }\end{array}$ & $\begin{array}{c}\text { End-user } \\
\text { satisfaction, } \\
\text { employee } \\
\text { productivity, Job } \\
\text { satisfaction, } \\
\text { organizational } \\
\text { commitment, role } \\
\text { overload, role } \\
\text { conflict, employee } \\
\text { innovation, }\end{array}$ & N/A \\
\hline $\begin{array}{l}\text { Shu et } \\
\text { al.2011 }\end{array}$ & Organization & $\begin{array}{c}\text { Organizational characteristics } \\
\text { (dependency on technology) } \\
\text { individual characteristics (self- } \\
\text { efficacy for computers) } \\
\end{array}$ & $\begin{array}{l}\text { Overload, invasion, } \\
\text { complexity, insecurity, } \\
\text { uncertainty }\end{array}$ & N/A & $\begin{array}{l}\text { Age, gender, } \\
\text { education. } \\
\text { Gender and age }\end{array}$ \\
\hline $\begin{array}{l}\text { Reidl et } \\
\text { al.2012 }\end{array}$ & Organization & N/A & System breakdown & $\begin{array}{l}\text { Stress hormone } \\
\text { cortisol }\end{array}$ & N/A \\
\hline $\begin{array}{l}\text { Maier et } \\
\text { al.2012 }\end{array}$ & Private & N/A & $\begin{array}{l}\text { Invasion, complexity, } \\
\text { uncertainty, pattern, } \\
\text { disclosure }\end{array}$ & $\begin{array}{l}\text { Satisfaction, } \\
\text { continuous usage } \\
\text { intention }\end{array}$ & $\begin{array}{l}\text { Attitudinal } \\
\text { beliefs, control } \\
\text { beliefs, } \\
\text { normative } \\
\text { beliefs, } \\
\text { disconfirmation }\end{array}$ \\
\hline $\begin{array}{l}\text { Maier et } \\
\text { al.2014 }\end{array}$ & Private & $\begin{array}{l}\text { characteristics (gender and age), } \\
\text { usage features (extent of usage, } \\
\text { virtual friends numbers), } \\
\text { relationship characteristics } \\
\text { (subjective social support and type) }\end{array}$ & Social overload & $\begin{array}{c}\text { Exhaustion, } \\
\text { satisfaction, } \\
\text { discontinuous usage } \\
\text { intention }\end{array}$ & N/A \\
\hline
\end{tabular}

\subsection{Work engagement}

Work engagement is a common concept, in business and academic industries. The term work engagement first appeared in the 90s and more than 200 scientific research have been conducted in the field. In daily life, the word engagement indicates commitment, passion, involvement, enthusiasm, effort, energy etc. according to Merriam Webster dictionary, work engagement is "emotional involvement or commitment" and the condition of being in "gear". The first researcher who described and conceptualized the term work engagement was Kahn according to [29]. He described work engagement as "harnessing of organization members' selves to their work role: in engagement, people employ and express themselves physically, cognitively, emotionally, mentally during role performance. In other terms, employees who are engaged put extra effort in their works as they identify with their jobs [29].

[29] describes work engagement as "a positive, fulfilling, work-related state of mind that is characterized by vigor, dedication, and absorption". Firstly, vigor means high level of energy and mental resilience, and the willingness to 
invest effort and persistence even in the face of difficulties. Secondly, dedication characterizes by a sense of significance, enthusiasm, inspiration, pride, and challenge. Thirdly, absorption is being fully focused and deeply engrossed in one's work whereby time passes quickly, and one has difficulties with detaching oneself from work. Moreover, work engagement is essential as it contributes to the bottom line of the organization, [44]. Similarly, work engagement is useful for both employees and organizations as engaged individuals are likely to demonstrate better work performance [44].

A review of literature shows that well-being is analyzed by employee engagement, which is most often interchangeable with work engagement. Work engagement can have a negative impact on employees' well-being. Work engagement has found to be crucially and positively connected to well-being. More, high engagement also results in optimistic, satisfied, and productive employees. For example, work engagement is associated with improved mental and physical well-being. Furthermore, work engagement is linked to reduce the risk of sickness absence, and it is the factor for several other job performance, and safety factors. Thus, a stress which is come from technology use might result in negative consequences along with avoiding of resisting to information and communication technologies. These, in general, have effects on individuals' psychological wellbeing and consequently on organizational performance [1].

Moreover, research found that companies lose approximately 2.27 million per year in Malaysian currency, which is equal to (73.1 days a year of productivity loss), and presenteeism issues such as being absent at work because of health issues from doing daily works. Hence, how capable the workplace is to avoid any kind of illnesses and foster well-being is useful for both the society and the organization. However, nowadays organizations' total focus is on the employees' physical health such as blood pressure, diabetes, smoking, weight issues, nutrition etc. But another important factor of employees' well-being is employee's mental health. Employees mental health reduces the bad effects of stress at work and will lead to satisfaction in life [1].

Moreover, research shows that there are two things that impacts work engagement: job resources and personal resources. Job resources such as social support (supervisor support), support from co-workers, performance evaluation, autonomy, personal development. Secondly, personal resources like self-efficacy, optimism, resilience, comping technique to aid employees to influence the success in their work environment or obtain success in their careers [11].

The Job Demand-Resource (JD-R) model is one of the popular theories to describe engagement. [27] in research showed that job and personal resources are positively linked to work engagement. According to the research, job resources indicate the physical, social and organizational features of the work which might: first, decrease job demands and its following physiological and psychological burdens. Second, be very practical in accomplishing job targets. Third, promote personal development. On the other hand, personal resources are good self-feedback which are associated with resiliency which means people feel their capabilities to control and affect their environment successfully. In addition, each organization's job resources that expect work engagement is different. Vital resources are chances for development, evaluation, performance, autonomy, abilities, leadership which are transformational, justice, and social support for co-workers or supervisors.

Several outcomes of work engagement include good attitude at work, good well-being and health, extra-role act, and job performance. In contrast to those who are not experiencing engagement, engaged employees think they are more committed to the firm, get absent less often, and they do not have the intention to leave the firm. In addition, they feel good and positive emotion, and appreciate the good mental health, especially if compared to those who are workaholic. To add more, they show initiative and have strong desire to learn continuously. All this, tell us that those who are engaged are capable and intend to go further or "go extra mile" for the firm [27].

moreover, research points out the interesting aspect of the work engagement which is its dark sides. Also, it is momentous to address this aspect of work engagement since it assists us to obtain a deeper comprehension of work engagement and the link for both organizations and the individuals. For instance, since work engagement has been most often linked to positive effect, its negative effect may appear not crucial. Nonetheless, its negative effect is also highly important for particular types of information process and might even promote creativity under some particular conditions [35]. [35] cited as the first experimental evidence which shows that great level of work engagement is linked to positive outcome at work but also a more negative outcomes in real life. The research demonstrated that work engagement was positively linked with organizational citizenship behavior, but also expected a very high degree of work-family conflict. The organizational citizenship behavior is a mediator between work-family conflict and work engagement. Hence, the research hints although OCB can be thought as helpful consequences of work engagement, similarly OCB has a damaging impact on life.

Similarly, recent qualitative research points out that keepers at the zoo, who think their jobs as kind of "calling" and demonstrated high-level of connection with their jobs, are wanting to give up private time, and comfort of their jobs or even pay. They say that individuals who think their work are me (calling) \& have strong connection with their jobs, also demonstrate high degree of engagement at work and also spend more of their resources such as personal ones like (personal time, solace and pay etc.) on their jobs that might have a damaging impact on their life at least in the long run. Additionally, work engagement may also have bad impacts of individual's life and may again have bad outcomes for parts of their jobs. A study found that work engagement expected a rise in job demand over time [35]. 


\subsection{Perceived supervisor support}

Perceived Supervisor Support (PSS), in the literature, is defined as an extent in which employees of an organization develop a feeling that their supervisor or manager acknowledges their contributions at work and also care about both their physical and mental well-being cited in [7]. Also, in the employees' development process, supervisors' support can be recognized as a major key of a supportive work environment. Literature also shows that workers' Perceived Supervisor Support in the activities of employees' developments have been shown to empirically impact employees' intentions to participate and the real participation ratio in the employees' development activities [7].

Moreover, employees might perceive support from their supervisors with respect to employees' professional development. To add more, those supervisors that talk about goal learning, giving evaluation feedbacks, and assist employees to advance their skills are perceived as supportive supervisors [7]. Furthermore, as described in Organizational Support theory, employees do not only make a global perception about their value from the organization's side, but then create a similar view of the level in which their supervisors' value their work and health [7].

Literature indicates that employees would think of their supervisors' favorable or unfavorable treatment toward them as a token of the organizations' degree of support since supervisors perform as agents of the organization they work for, who have accountability to direct and assess their employees' performance as cited in [20]. Additionally, according to a study, a good treatment by supervisors toward their subordinates contributes positively to the perceived organizational support in a way that employees would view the good treatment to the organization's rules, culture, and procedures not the supervisors' normal behavior. Hence, employees know that their supervisors communicate their feedbacks to the upper levels of the organizations management which also intensifies the belief to which employees associate the supervisor with the perceived organizational support as cited by [7].

According to research by [18] there are several useful ways to manage your stress like social support or physical exercises. Generally, it is very helpful to have a support when managing stress. Particularly supervisor support which is negatively associated stress but positively linked to workability [18].

Organizational support theory suggests that employees characterize the organization and perceive the level in which the organization worries about their health and returns such support from employees by being committed, loyal, and have high performance. This is significant because it has been proven that employees who experience support from their supervisors are likely to be more engaged but less likely to experience high degree of stress. Organizational support, in particular, like supervisor support can play a vital role to decrease work stress. The phrase supervisor support is described as "the degree to which employees are under the general impression that their managers appreciate their contributions, are supportive and care about their subordinates' well-being" as cited in [30].

[10] in research found that practitioners and researchers have utilized Perceived Organizational Support and Perceived Supervisor Support as a predicators of work engagement. Perceived Organizational Support (POS) is a general belief that employees have about their organizations and in which they feel that their organizations care about their health and values their good work. According to the research which contained of 102 workers from different organizations, reaching to a conclusion that those who have high POS and PSS are like to be more engaged workers than those who are not. The results gave a very significant connection between POS and PSS to work engagement.

Moreover, another study also predicted work engagement which included 130 employees in IT sector. The average ages of the workers were 27 years old and $42 \%$ were females. The result obtained from this research gave a positive and strong correlation between the POS and PSS and work engagement. This indicates that although enhanced POS and PSS might result in higher work engagement for employees, probably the PSS factors are more crucial factors than POS [10]. For this reason, if employees have high supervisor support, it will result in employee engagement and when employees are engaged and full of motivation, enthusiasm, have initiative at work, have high performance with high quality of work and they will be more dedicated workers too [19].

\section{Research Model \& Hypothesis}

The research model of this research is illustrated clearly in figure 1. Further, this research concentrates on the impacts of technostress on employees' well-being, the role of work engagement and of perceived supervisor support. Furthermore, the technostress is the independent variable while work engagement and perceived supervisor support are dependent variables. Moreover, the researcher proposed the following hypothesis based on reviewing selected literature.

$H_{0 A}$ : Technostress has a negative effect on Work Engagement.

$H_{0 B}$ : Technostress has a negative effect of Perceived Supervisor Support.

$H_{0 C}$ : Perceived Supervisor support has a positive effect on work engagement.

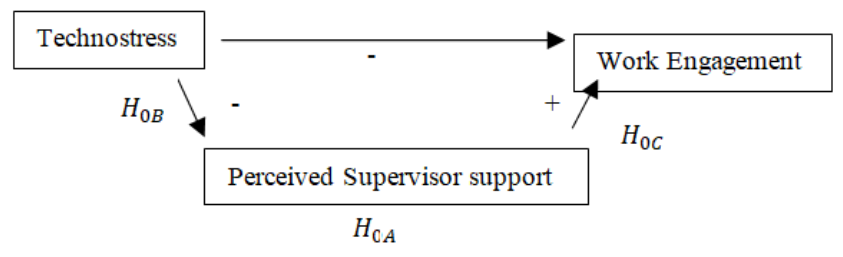

Figure 1: Research model 


\section{Research Methodology}

\subsection{Method}

This research uses a quantitative research design because quantitative methodology was appropriate since it yielded rigorous, generalizable data and the results we based on statistical proof [43]. Quantitative was again appropriate because (a) analyze the relationship between variables, (b) test theories by using data numbers.

\subsection{Design}

Correlational research design was appropriate which contains Pearson correlations coefficient and Liker-scale data. According to [43] Liker-scale data is crucial for examining and measuring the opinions and comprehending characteristics of individuals when analyzing correlational and Pearson's procedures. The best design for testing the relationship between technostress, work engagement, and perceived supervisor support was correlational design using Pearson's.

\subsection{Sample Procedure}

The population of this research were employees of a developing country of Iraq, but the sample were those employees who used ICT on a daily basis during a world pandemic - COVID-19. According to (Stina, Julia, \& Linda, 2020) when researchers conduct a quantitative research, researchers sometimes need to select a particular part to study. They claim that sampling is conducted because it is unlikely that the researcher can reach the entire population. To test the hypothesis and collect data, an online survey was created via google form and it was approved by Istanbul Aydin University's Ethical Committee before sending it out to participants. The link to the online questionnaire was shared in the summer of 2020 on social media networks such as "Facebook" on business and work groups, "LinkedIn", as well as sent via direct email to anyone who were not on social media to reach as much as participants as possible. Hence, the participants were chosen through convenient snowball sampling. They self-reported their opinion in private setting filling out the survey.

\subsection{Control Variable}

Based on research by [37] since the dependent variables' quality might be affected by factors other than the hypothesized variables in the research model, some appropriate controls have been incorporated in the research so as to better comprehend the variance described by the research variables. Moreover, according to [6] control variables are included in order to exclude the possible impact of these variables on the relationship. Also, the literature reaffirms that these control variables are related to technostress or suspected to affect the degree of technostress perceived by employees [3]. The control variables were age, gender, marital status, highest level of education, income, and computer literacy, and the tenure.

\subsection{Measures}

4.5.1. Technostress: this variable is measured with a 23item scale which includes techno-overload, technoinvasion, techno-complexity, techno-insecurity, and techno-uncertainty. Participants were asked to answer the questions on a five-point Likert scale ranging from "strongly disagree" to "strongly agree". The scale was created by [45].

4.5.2. Work engagement: Work-related well-being of employees is measured by work engagement according to [29], [5], [12], [34]. This research used the short version of "Utrecht Work Engagement Scale" by [28] to measure work related well-being which consists of 9 items. Participants had to choose how they felt at work by choosing 5 Liker Scale ranging from "never" to "always".

4.5.3. Perceived supervisor support: the perceived supervisor support is measured with 13 item which participants had the options to choose a 5-point Likert scale ranging from (strongly disagree to strongly agree). Perceived supervisor support scale was measured with [46].

\section{Data Analysis}

The survey questionnaire of this quantitative research is analyzed by Jamovi 1.6.23. The first step before doing anything else was coding the participant's answers in an Excel sheet [39]. The second step was to carry out data mining such as missing data analysis. The third step was to do a Cronbach's Alpha test. The Cronbach's Alpha test is used to test the internal consistency. Moreover, it measures the range in Cronbach's Alpha that is between 0 and 1 . Additionally, if the score is higher than 0.7, it means it is reliable, regarding a particular type of question conducted in the test [39]. The fourth step was to conduct the descriptive statistics analysis. After descriptive statistics, came the fifth step which was Pearson's Correlation Analysis test is a technique to analyze whether the variables were positively or negatively related to each other. Lastly, regression analysis was conducted to predict what will happen in the future.

\section{Findings}

\subsection{Descriptive Statistics}

The analysis of the demographics yielded the following descriptive statistic results in table 2 . 
Table 2: descriptive statistics of the participants demographics

\begin{tabular}{|c|c|c|c|}
\hline Item $(\mathrm{N}=179)$ & Category & Frequency & Percentage \\
\hline \multirow{6}{*}{ Age } & Under 20 & 5 & 2.8 \\
\hline & 20 to 30 & 115 & 64.2 \\
\hline & 31 to 40 & 47 & 26.3 \\
\hline & 41 to 50 & 8 & 4.5 \\
\hline & 51 to 60 & 2 & 1.1 \\
\hline & $60+$ & 2 & 1.1 \\
\hline \multirow{2}{*}{ Gender } & Male & 117 & 65.4 \\
\hline & Female & 62 & 34.6 \\
\hline \multirow{3}{*}{ Marital Status } & Single & 108 & 60.3 \\
\hline & Married & 69 & 38.5 \\
\hline & Widowed & 2 & 1.1 \\
\hline \multirow{7}{*}{ Qualification } & Elementary school & 5 & 2.8 \\
\hline & Secondary school & 2 & 1.1 \\
\hline & Semi-higher/vocational education & 10 & 5.6 \\
\hline & Bachelor's degree & 101 & 56.4 \\
\hline & Master's degree & 49 & 27.4 \\
\hline & Doctorate degree & 5 & 2.8 \\
\hline & Other: & 7 & 3.9 \\
\hline \multirow{7}{*}{ Income } & $250-500$ & 49 & 27.4 \\
\hline & $500-700$ & 38 & 21.2 \\
\hline & $700-100$ & 26 & 14.5 \\
\hline & $1000-1200$ & 16 & 8.9 \\
\hline & $1200-1500$ & 14 & 7.8 \\
\hline & 1500 or above & 23 & 12.8 \\
\hline & Other & 13 & 7.3 \\
\hline \multirow{5}{*}{ Computer Literacy } & Terrible & 4 & 2.2 \\
\hline & Bad & 8 & 4.5 \\
\hline & Fair & 28 & 15.6 \\
\hline & Good & 97 & 54.2 \\
\hline & Excellent & 42 & 23.5 \\
\hline \multirow{7}{*}{ Current Profession } & Less than 6 months & 26 & 14.5 \\
\hline & 6 months-1 year & 22 & 12.3 \\
\hline & $1-3$ years & 40 & 22.3 \\
\hline & 4-8 years & 59 & 33.0 \\
\hline & $9-13$ years & 24 & 13.4 \\
\hline & $14-17$ years & 3 & 1.7 \\
\hline & 18 or more years & 5 & 2.8 \\
\hline \multirow{7}{*}{ Tenure } & Less than 6 months & 43 & 24.0 \\
\hline & 6 months-1 year & 25 & 14.0 \\
\hline & 1-3 years & 52 & 29.1 \\
\hline & 4-8 years & 36 & 20.1 \\
\hline & $9-13$ years & 18 & 10.1 \\
\hline & $14-17$ years & 1 & 0.6 \\
\hline & 18 or more years & 4 & 2.2 \\
\hline
\end{tabular}

\subsection{Cronbach's Alpha:}

To confirm the scales' reliability and validity, Cronbach's Alpha analysis has been conducted for the three main variables. More, as it can been seen in Table 3, all the variables are internally consistent because the reliability coefficient is more than 0.7 for each of them and that is considered a reliable and acceptable threshold according to [3].

Table 3: Scale Reliability Coefficient for the Main Variables

\begin{tabular}{|c|c|c|}
\hline \multicolumn{4}{|c|}{ Scale } & $\begin{array}{c}\text { Number of } \\
\text { items }\end{array}$ & $\begin{array}{c}\text { Cronbach's } \\
\boldsymbol{\alpha}\end{array}$ \\
\hline Technostress & 23 & $\mathbf{0 . 8 7 1 ^ { * }}$ \\
\hline Work Engagement & 9 & $\mathbf{0 . 7 6 2}$ \\
\hline $\begin{array}{c}\text { Perceived Supervisor } \\
\text { Support }\end{array}$ & 13 & $\mathbf{0 . 9 1 9 *}$ \\
\hline
\end{tabular}

\subsection{Hypothesis Testing}

\subsubsection{Hypothesis $0 \mathrm{~A}$}

Based on our result from the regression analysis, we are going to accept the null hypothesis since the f-value is equal to 1 and the $p$ value is $>0.05$. Additionally, we can observe the nature of the relationship between our variables by looking at the standardized estimate (S. Est.) column in the model coefficient table. The standardized beta coefficient linked with technostress is 0.0750 which indicates that there is a positive but weak relation with work engagement. Therefore, technostress does not predict work engagement as the regression model is unsignificant and thus the $H_{0 A}$ cannot be supported. Table 4 illustrates the result of hypothesis $0 \mathrm{~A}$.

$H_{0 A}$ : Technostress has a negative effect on Work Engagement 
Table 4: the model summary of technostress and work engagement

\begin{tabular}{|l|l|c|l|l|l|l|l|l|}
\hline mo & $\mathbf{R}$ & $\boldsymbol{R}^{\mathbf{2}}$ & Adjus & $\mathbf{f}$ & $\mathbf{d f}$ & $\mathbf{d f}$ & $\mathbf{p}$ & S. \\
\hline 1 & 0.07 & 0.00 & $8.64 \mathrm{e}-$ & 1. & 1 & 17 & 0.3 & 0.07 \\
\hline
\end{tabular}

6.3.2. Hypothesis 0B: technostress does not predict perceived supervisor support since the regression model is unsignificant and therefore the $H_{O B}$ cannot be supported. Table 4 shows the model summary.

$H_{0 B}$ : Technostress has a negative effect of Perceived Supervisor Support

Table 5: The Model Summary of technostress and perceived supervisor support

\begin{tabular}{|c|c|c|c|c|c|c|c|c|}
\hline $\begin{array}{c}\text { mod } \\
\text { el }\end{array}$ & $\mathbf{R}$ & $\boldsymbol{R}^{\mathbf{2}}$ & $\begin{array}{c}\text { Adjust } \\
\text { ed } \boldsymbol{R}^{\mathbf{2}}\end{array}$ & $\mathbf{f}$ & $\begin{array}{c}\mathbf{d f} \\
\mathbf{1}\end{array}$ & $\begin{array}{c}\mathbf{d f} \\
\mathbf{2}\end{array}$ & $\mathbf{p}$ & $\begin{array}{c}\text { S. } \\
\text { Est. }\end{array}$ \\
\hline 1 & $\begin{array}{c}0.07 \\
58\end{array}$ & $\begin{array}{c}0.005 \\
74\end{array}$ & $\begin{array}{c}1.24 \mathrm{e}- \\
4\end{array}$ & $\begin{array}{c}1.0 \\
2\end{array}$ & 1 & $\begin{array}{c}17 \\
7\end{array}$ & $\begin{array}{c}0.3 \\
13\end{array}$ & $\begin{array}{c}0.07 \\
58\end{array}$ \\
\hline
\end{tabular}

6.3.3 hypothesis $0 \mathrm{C}$ : perceived supervisor support predicts work engagement and there is a positive strong correlation between them because the regression model is significant and therefore the $H_{3}$ is supported. Table 6 shows the model summary.

$\mathrm{H}_{3}$ : Perceived Supervisor support has a positive effect on work engagement.

Table 6: The Model Summary of perceived supervisor support and work engagement

\begin{tabular}{|c|c|c|c|c|c|c|c|c|}
\hline $\begin{array}{c}\text { mod } \\
\text { el }\end{array}$ & $\mathbf{R}$ & $\boldsymbol{R}^{\mathbf{2}}$ & $\begin{array}{c}\text { Adjust } \\
\text { ed } \boldsymbol{R}^{\mathbf{2}}\end{array}$ & $\mathbf{f}$ & $\begin{array}{c}\mathbf{d f} \\
\mathbf{1}\end{array}$ & $\begin{array}{c}\mathbf{d f} \\
\mathbf{2}\end{array}$ & $\mathbf{p}$ & $\begin{array}{c}\text { S. } \\
\text { Est. }\end{array}$ \\
\hline 1 & $\begin{array}{c}0.40 \\
9\end{array}$ & $\begin{array}{c}0.16 \\
8\end{array}$ & 163 & $\begin{array}{c}35 . \\
6\end{array}$ & 1 & $\begin{array}{c}17 \\
7\end{array}$ & $\begin{array}{c}<.00 \\
1\end{array}$ & $\begin{array}{c}0.40 \\
9\end{array}$ \\
\hline
\end{tabular}

\section{Conclusion \& Recommendation}

The aim of this research is to examine the impacts of technostress on employees' well-being and the role of perceived supervisor support in a developing country such as Iraq during the COVID-19 pandemic.

Findings assert that contrary to the previous research in the literature such as those of [41], [22] and [4] this research confirms that there is no relationship or weak positive relationship between technostress and work engagement per se while at the same time this research is similar to those of [21] and [30]. Additionally, this research finds no relationship or weak positive relationship between technostress and perceived supervisor support at least for employees in Iraq especially during COVID-19 which are very interesting contrary to the research of [18] and [30]. Furthermore, this research reaffirms the results of [19] and [26] that there is a significant positive relationship between perceived supervisor support and work engagement, which indicates that supervisors' support is very crucial in order to enhance employees' well-being in times of crisis. The result also implies that contrary to the theorized relationship, there is a positive association between technostress and work engagement although this association is weak but still positive. This means that the results or outcomes of technostress or stress on employees does not necessarily be negative i. e., the presence of stress can in fact serve as a motivating factor. In addition, the practical implication for this research is that organizations and top management in Iraq should understand that in spite of the disadvantages of the usage of technology at work and what has been written in the literature, technology can have positive or even no correlation in the lives of employees which affects employee's performance, engagement and well-being though may be true only in the times of a crisis. Moreover, decision makers such as HR can make use of this research's survey in order to measure technostress, work engagement and perceived supervisor support within their organization and know if it is applicable to take measures to combat technostress. In order to do this, HR decision makers in Iraq need to look for a balanced use of technology and study the impacts of it while at the same time knowing how to recover from the bad effects effectively.

Nonetheless, this research has the following limitations; firstly, the sampling method for this study was convenient sampling method via sharing the survey through Facebook work groups, LinkedIn, e-mails, Friends on Facebook and other social media platforms etc., and only those people were reached who has access to those networks. Second, another limitation can be the fluency of the English language. The respondents who filled out the survey were not native English speakers, which could have raised some issues and difficulties in understanding the questions in a correct way as it had to be translated. Third, when future research is conducted and the samples should be bigger, for instance conducting the questionnaire in several cities in Iraq not only in couple of cities so that the results can be generalizable to the whole population. In addition, instead of cross sectional, a longitudinal study would assist to test the relationship between the items of the model and lets the researchers to assess the changes and any trends in the impacts of the three variables

\section{References}

[1] AbdulRasool, M. S., \& Mat Isa, N. A. (2020). The Moderating Effects Of Self-Efficacy Between Physical Activity Towards Employee's Well-Being During Covid-19 Pandemic: A Conceptual Framework. European Journal of Molecular \& Clinical Medicine, 7 (6), 1575-1583

[2] Ajibola, k. s. (2018). Technostress: human resource management concerns for employee wellness and job performance. uniosun international journal of business and administration, 57-68.

[3] Andrulli, R. (2020). The Impact of Technostress on Well-being in Times of COVID-19 and New Ways of Working: The Mediating Roles of the Need for Recovery and Work Engagement. Liège \& Maastricht.

[4] Atanasoff, L., \& Venable, M. A. (2017). Technostress: Implications for Adults in the Workforce. The Career Development Quarterly, 65, 326-338. doi: https://doi.org/10.1002/cdq.12111

[5] Booker, L.-j. (2017). Components of Work-related Well-being.49.

[6] Boutchich, M. (2020). Technostress and quality of care; does leadership help? 
[7] Brands, T. (2016). Perceived supervisor support, Motivation through expectation and Different functions organizational actors attribute to HRD as antecedents of employees' Participation intentions in HRD. Master Thesis Human Resource Studies. The Netherland: Tilburg University. Retrieved from http://arno. uvt. nl/show. cgi?fid=139948

[8] Brennan, F. (2021). Technostress and Leadership: A Case Study in Higher Education During the COVID19 Crisis. Tampere University of Applied Sciences.

[9] Brod, C. (1984). Technostress: The Human Cost Of The Computer Revolution. massachusetts: AddisonWesley Publishing Company,.

[10] Burns, K. L. (2016). Perceived Organizational Support And Perceived Supervisor Support As Antecedents Of Work Engagement. Master's Theses.4678; San José State University. doi: https://doi.org/10.31979/etd.8hf7-dh9p

[11] Fazlurrahman, H., Wijayati, D. T., Hadi, H. K., Rahman, Z., Nugrohoseno, D., \& Rahman, M. F. (2020). Analysis of work engagement measurement at work from home due to the effect of Covid-19 pandemic. Technium Social Sciences Journal, 14, 363375.

[12]Fisher, C. D. (2013). Conceptualizing and Measuring Wellbeing at Work. John Wiley \& Sons, Inc., 8 (16). doi: wbwell018

[13] International Labour Organization. (2020). teleworking during the covid-19 pandemic and beyond; a practical guide.

[14] Kurnia, N. P. (2015). The Impact of Stress at Work on Employee's Psychological Well-being in Jakarta. iBuss Management, 3 (2), 68-76.

[15] Mahapatra, M., \& Pillai, R. (2018). Technostress in organizations: A review of literature. ECIS 2018 Proceedings. Portsmouth: Association for Information Systems AIS Electronic Library (AISeL.

[16] Mahboob, A., \& Khan, T. (2016). Technostress and Its Management Techniques: A Literature Review. Journal of Human Resource Management, 4 (3), 2831. doi: 10.11648/j. jhrm.20160403.12

[17] Maier, C. (2014). Technostress: Theoretical Foundation and Empirical Evidence. University of Bamberg.

[18] Morgan, J. W., \& Gore, J. S. (2019). The Influence of Technological Reliability and Supervisor Supportiveness on Work Stress. Kentucky Journal of Undergraduate Scholarship, 3 (1), 47-58. Retrieved from https://encompass. eku. edu/kjus/vol3/iss1/6

[19] Nalini, G., \& Mohid, K. (2019). Employee Engagement: a Literature Review. International Journal of Research and Analytical Reviews, 6 (1), 524-527.

[20]Nielsen, S. K. (2006). A Multi-Source Model of Perceived Organizational Support and Performance. PhD diss., University of Tennessee. Retrieved from https://trace. tennessee. edu/utk_graddiss/2000

[21] Okolo, D., Kamarudin, S., \& Ahmad, U. N. (2018). An Exploration of the Relationship between Technostress, Employee Engagement and Job Design from the Nigerian Banking Employee's Perspective.
Management Dynamics in the Knowledge Economy, 6 (4), 511-530. doi: 10.25019/MDKE/6.4.01

[22] Pfaffinger, K. F., Reif, J. A., \& Spieß, E. (2020). When and why telepressure and technostress creators impair employee well-being. International Journal of. doi: https://doi.org/10.1080/10803548.2020.1846376

[23] Popescu, C., Ilie, O.-M., \& Bondac, G. (2017). The Impact of Technostress on Employees in a Digital Society.508-515.

[24] Purisiol, S. (2020). The Effects of Technostress on Well-Being and Performance. The Role of Social Support. Tilburg University.

[25] Ragu-Nathan, T. S., Tarafdar, M., Ragu-Nathan, B. S., \& Tu, Q. (2008). The Consequences of Technostress for End Users in Organizations: Conceptual Development and Empirical Validation. Information Systems Research, 19 (4), 417-433.

[26] Savolainen, I., Oksa, R., Savela, N., Celuch, M., \& Oksanen, A. (2021). COVID-19 Anxiety-A Longitudinal Survey Study of Psychological and Situational Risks among Finnish Workers. Int. J. Environ. Res. Public Health, 18 (794). doi: https://doi.org/10.3390/ijerph18020794

[27] Schaufeli, W. B. (2012). Work Engagement. What Do We Know and Where Do We Go? Romanian Journal of Applied Psychology, 14 (1), 3-10.

[28] Schaufeli, W. B., \& Salanova, M. (2007). Efficacy or inefficacy, that's the question: Burnout and work engagement, and their relationships with efficacy beliefs. Anxiety, Stress, and Coping, 20 (2), 177-196. doi: https://doi.org/10.1080/10615800701217878

[29] Schaufeli, W. B., Salanova, M., Alez-RomA, V. G., \& Bakker, A. B. (2002). The Measurement of Engagement and Burnout: a Two Sample Confirmatory Factor Analytic Approach. Journal of Happiness Studies, 3, 71-92. doi: https://doi.org/10.1023/A: 1015630930326

[30] Schmidt, S. (2018). Technostress and its Effects on Exhaustion and Engagement. University of Amesterdam.

[31] Sekaran, U., \& Bougie, R. (2016). Research Methods for Business: A Skill-Building Approach (Seven ed.). West Sussex, UK: John Wiley \& Sons Ltd.

[32] Sheldon, N. (2021). Six Ways to Help Workers Prevent And Overcome Technostress. Retrieved from weareumi. co. uk: https://www.weareumi. co. uk/news/sectors/business-services/six-ways-to-helpworkers-prevent-and-overcome-technostress

[33] Sheldon, N. (2021). Six Ways to Help Workers Prevent And Overcome Technostress. Retrieved from weareumi. co. uk: https://www.weareumi. co. uk/news/sectors/business-services/six-ways-to-helpworkers-prevent-and-overcome-technostress

[34] Soh, M., Zarola, A., Palaiou, K., \& Furnham, A. (2016). Work-related well-being. Health Psychology Open, 1 (11). doi: https://doi.org/10.1177\%2F2055102916628380

[35] Sonnentag, S. (2011). Research on work engagement is well and alive. European Journal of Work And Organizational Psychology, 20 (1), 29-38. doi: https://doi.org/10.1080/1359432X.2010.510639 
[36] Spiros, A. (2019). Mitigating Technostress in New Knowledge Workers Through Perceived Self-Efficacy. University of Jyväskylä.

[37] Srivastava, S. C., Chandra, S., \& Shirish, A. (2015). Technostress creators and job outcomes: theorising the moderating influence of personality traits. Information System Journal, 25, 355-401. doi: https://doi.org/10.1111/isj.12067

[38] Stich, J.-f., Tarafdar, M., \& Cooper, S. C. (2018). Electronic Communication in the Workplace: Boon or Bane? Journal of Organizational Effectiveness: People and Performance, 2051-6614. doi: https://doi.org/10.1108/JOEPP-05-2017-0046

[39] Stina, O. S., Julia, P., \& Linda, Å. (2020). The Effects of Technostress through Virtual Meetings on Employee-level. Mälardalen University.

[40] Upadhyaya, P., \& Vrinda. (2021). Impact of technostress on academic productivity of university students. Education and Information Technologies, 26, 1647-1664. doi: https://doi.org/10.1007/s10639-02010319-9

[41] vaneck, M. (2005). Technostress and Work Wellness. North-West University.

[42] Vaziri, H., Casper, W. J., Wayne, J. H., \& Matthews, R. A. (2020). Changes to the Work-Family Interface during the COVID-19 Pandemic: Examining Predictors and Implications Using Latent Transition Analysis. Journal of Applied Psychology, 105 (10), 1073-1087. doi: http://dx.doi.org/10.1037/ap10000819

[43] Walton, K. (2019). Relationship between Technostress Dimensions and Employee Productivity. Walden Dissertations and Doctoral Studies.

[44] Wang, X., Tan, S. C., \& Li, L. (2020). Measuring university students' technostress in technologyenhanced learning: Scale development and validation. Australasian Journal of Educational Technology, 36 (4). doi: https://doi.org/10.14742/ajet.5329

[45] Yongxing, G., Hongfei, D., Baoguo, X., \& Lei, M. (2017). Work engagement and job performance: the moderating role of perceived organizational support. anales de psicología, 33 (3), 708-713. doi: http://dx.doi.org/10.6018/analesps.33.3.238571

[46] Tarafdar, M., Tu, Q., Ragu-Nathan, B. S., \& RaguNathan, T. S. (2007). The Impact of Technostress on Role Stress and Productivity. Journal of Management Information Systems, 24 (1), 301-328. doi: 10.2753/MIS0742-1222240109

[47] Eisenberger, R., Stinglhamber, F., Vandenberghe, C., Sucharski, I. L., \& Rhoades, L. (2002). Perceived supervisor support: Contributions to perceived organizational support and employee retention. Journal of Applied Psychology, 87 (3), 565-573. doi: https://doi.org/10.1037/0021-9010.87.3.565 